\author{
N.A. Bissembayeva ${ }^{1 *}$, S.A. Nurgaliyeva, ${ }^{2}$ P.Z. Ishanov $^{3}$ \\ ${ }^{1}$ Pavlodar Pedagogical University, Kazakhstan \\ ${ }^{2}$ Agri İbrahim Çeçen Üniversitesi, Republic of Turkey \\ ${ }^{3}$ Karagandy University of the name of academician E.A. Buketov, Kazakhstan \\ (Corresponding author's E-mail: bissembayevana@mail.ru)

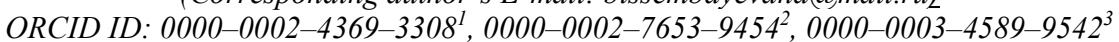

\title{
Teacher ethics as a research problem: a narrative review of the scholarly writings
}

\begin{abstract}
The authors explore a vital problem of our time, i.e., the professional ethics of teachers. Considering the relevance of this problem, the authors of this paper initiated a study devoted to a narrative review of scientific sources of foreign authors from far and near abroad on teaching professional ethics to future teachers, synthesizing points of view on key aspects of this problem. The research was carried out by the method of systematization and generalization of pedagogical experience in the aspect of the issue under study, thus the authors of this work tried to bring experimental facts of scientific views of authors from far and near abroad into the system of observation. According to the results of interviews with graduate students, the majority of respondents have low indicators of knowledge and skills in the field of professional ethics by the end of university, which will have a negative impact on their future professional activities. The results of research will expand scientific knowledge on the problem of forming professional ethics among students-future teachers and complement the main provisions of professional ethics and concepts of moral and professional development of the individual, enriching the theory and methodology of continuing professional education.
\end{abstract}

Keywords: ethics, higher school, professional ethics, formation, interviews, observations, teaching experience, theory and methodology.

\section{Introduction}

B. Maxwell and M. Schwimmer consider: “...the preparing future teachers to assume the role of moral models for their students was a primary concern of teacher education in Europe and North America from the beginning of formalized teacher education. Traditionally, teacher educators were preoccupied with impressing on prospective teachers the need to adhere to strict moral standards for their behavior as much in their private lives as in their work with children and young people in schools. This aspect of teacher education began to recede into the background as teacher education was brought under the auspices of the university through the middle decades of the twentieth century (Labaree, 2008). In the 1980s, however, two discourses in teacher education appeared to converge, making it clear to many that a renewed prioritization of the ethical and moral dimensions of teaching in teacher education was urgent, if not a foregone conclusion. The first discourse, widely associated with Alan Tom's (1984) book "Teaching as a Moral Craft", centered on the idea that "the act of teaching is moral" in the sense that education inevitably involves attempting to transform people in ways that are considered to be good or worthwhile (cf. Peters, 1966). What incited Tom (1984) and subsequent scholars (e.g., Fenstermacher, 2001; Goodlad, Soder, \& Sirotnik, 1990; Hansen, 2001) to explore in this direction was a concern about the future of teacher education. In a critique that still seems fresh today, Tom (1980) argued that the increasingly dominant 'applied-science metaphor' of teaching highlighted the technical and analytic aspects of teaching while rendering obscure to those involved in teacher education that teaching is necessarily as much about transmitting values and social ideals as it is about transmitting knowledge and skills.

The second discourse, which emanated from the reform movement in teacher education launched by "A Nation at Risk" (National Commission on Excellence in Education, 1983), was concerned with aligning teacher education with broader trends in ethics education in the professions. In the wake of "A Nation at Risk", two major commissions on teacher education were struck in 1986, the Holmes Group initiative and the Carnegie Task Force. Both groups' analyses of the state of teacher education in the United States, as well as their recommendations about how to improve teacher education, took as a touchstone the model of professional education that had emerged in medicine over the course of the twentieth century" (Wiggins, 1986) [1]. 


\section{Methods}

The following research methods were used: theoretical: analysis of literary sources, study and analysis of regulatory documents, comparison.

\section{Experimental}

E. Campbell argues: “.... a theoretical discussion of the process of developing a professional code of ethics for teachers. Two underlying assumptions pervade the article. Firstly, that increased awareness of the ethical dimensions and responsibilities of teaching is essential for both enhanced professionalism and, more significantly, improved practice. Secondly, that while a code of ethics may not advance the ultimate route to such awareness, it should be able to contribute broadly and positively to a deeper examination of ethics in teaching as long as its limitations are recognized and acknowledged. Six key issues and questions that highlight the complexities that those involved in the development of a code of professional ethics should address are discussed. While this article intends to provoke thoughts relevant to any organization grappling with its own ethical code, its primary context is the Ontario College of Teachers (Ontario, Canada), whose work in this area is newly emerging" [2].

M. Schwimmer and B. Maxwell provide that "...the value of adopting a code of professional ethics for teachers. After having underlined how a code of ethics stands to benefits a community of educators - namely, by providing a mechanism for regulating autonomy and promoting a shared professional ethic — the article examines the principal arguments against codes of ethics. Three arguments are presented and analyzed in light of the codes of teacher ethics in place elsewhere in Canada. We conclude that a code of ethics must meet three conditions in order for it to be favorable to autonomous judgment rather than blind adhesion to pre-established norms: openness of meaning, space for dissidence, and avoidance of moralistic language" [3].

Worldwide there is a growing expectation that teachers will act in a "professional" manner. Professionalism in this regard includes identification of a unique body of occupational knowledge, adherence to desirable standards of behavior, processes to hold members to account and commitment to what the profession regards as morally right or good. In other words, as ethical conduct. Teaching ethically involves making reasoned decisions about what to do in order to achieve the most good for learners. Often this involves a complex interplay between current context, past experience and personal beliefs and values. However, teacher education and accountability frameworks typically give priority to the "practical rationality" of planning, delivery and assessment of the official curriculum, not the "value rationality" involved in exploring the ethics of teaching in difficult practical circumstances [4].

Research on teacher ethics and the moral dimensions of teaching has contributed to extensive and valuable knowledge, which has sometimes led to constructive syntheses of positions. Four research problems which have been elucidated are discussed in the article by G. Colnerud: the relationship between care and justice, the conflict between the ethics of virtue and the ethics of rules, the relationship between moral education and professional ethics and what is morally significant in the teaching profession. Furthermore, an invitation to renew the discussion and formulate the next generation of research problems is made. Two issues are proposed. First, to answer the question why is it so difficult to be a morally good teacher and, second, teachers' moral responsibility for the content taught [5].

\section{Results and Discussion}

The rationale, research background and concept of this study on the forms and dimensions of teachers' professional ethics are presented by the K. Aurin and M. Maurer. Questions of particular interest are: which ethical dimensions with respect to central fields of action are teachers most aware of? To what extent does the importance they attach to these dimensions vary? To what degree does consensus exist among teachers? Are there differences in the form of ethics between schools, and what factors affect these differences? [6].

Nancy K. Freeman considers that the codes of professional ethics are adopted by professional organizations to supplement personal morality and guide practice. It is critically important that students striving to become professional educators know and able to apply applicable codes. But finding useful codes is not an easy task, and most existing codes have generated little commentary. The National Association for the Education of Young Children (NAEYC) has a code that can be helpful to students pursuing various teaching certifications. This Code and its interpretive literature are a resource that teacher educators should be using to help their students become informed about the ethics of their profession until groups of educators develop 
discipline-specific codes and accompanying interpretive literature. In this time of accountability ethics taught in ways that demonstrate sensitivity to students' gender, age, ethnicity, and developmental characteristics belong as a cornerstone of preservice teacher education [7].

N.V. Belinova et al. consider the pedagogical conditions of professional ethics of future teachers, which is believed to be one of the momentous directions of teachers' training, on the basis of fundamental principles of human morality, ethical and humanistic ideals and principles specific to the pedagogical profession. The professional ethics of the teacher is recognized as a scientific field that studies manifestations of morality and principles of professional ethics in teaching, patterns of behavior and relationships in the system "teacher" - "student as a future teacher", thus providing rules and norms of educational activities, expressed in the form of ethics codes. It is demonstrated in the article that the professional activity of the teacher in the educational organization from the standpoint of ethics is a system based on the principles of global, professional, educational and personal ethics [8].

M. Gluchmanova points out the importance of ethics in the teaching profession and stresses the importance of ethics in education because it constitutes the repository of social and cultural values, and is the medium of historical memory. In common usage multicultural education generally refers to education about different ethnic groups. As dialogue on cultural difference and education has spread to other nations, it has become more sharply focused on complex issues of identity, diversity, and citizenship. "The relationships between democracy, citizenship, and education cannot be treated in isolation from the question of multiculturalism". Several vectors of globalization have converged to raise the topic of multicultural education to the level of public, or at least professional, debate around the world today. The increasing cross-national mobility of people and the transnational communication of ideas that took place in the twenty-first century have fed into the contours of diversity around the world. It has also led to international dialogue. With increased human mobility and increasingly thick networks of communication, the common social fact of unequal educational experiences and outcomes is increasingly the subject of transnational dialogue. Educators around the world are faced with new challenges of balancing local, national, and global norms and morals as well as ethical values in the process of educating children. While fostering a sense of citizenship remains an important function of mass schooling, it is becoming less and less viable to do so at the expense of socializing children for their futures in a global society [9].

Many teacher education programs focus minimal attention on the ethical, political, social, and cultural dimensions of teaching. These four factors construct and sustain critical aspects of schooling for all children and are major barriers to the achievement of parity in education for students commonly marginalized in the educative processes in school. All teacher educators shoulder the responsibility of helping prospective teachers become routinely reflective regarding moral and ethical issues that are often "conversations not had" and subsequently impair opportunities for many students to experience positive school outcomes [10].

Soltis discusses the importance of teaching professional ethics in teacher education programs. Formal ethical codes, such as the one established by the NEA, provide a foundation for ethical decision ranking, but they also may leave prospective teachers ill-equipped to deal with the complexities of novel or unique problem situations. Teachers educators, the author argues, must elevate the ethics of educators before starting to deal with the multitude of moral realities of the world of work. Once such sensitivity or awareness arises, teachers need to develop strategies and skills to diagnose ethical issues and make informed ethical judgments. Soltis provides examples of how such an ethical quirk can be supported in a training program without simultaneously encouraging ethical relativism [11].

Speaking about the profession of teacher it is necessary to consider contemporary global ethical issues in education and educational research. There is an opportunity for students to develop a critical stance towards some of the most pressing ethical issues in education and educational research in contemporary societies. In a school context and with the support of school polices, programs and practices ethical education helps students to develop, for example, in depth knowledge and awareness of their own and other cultures [12].

In the higher education settings, the following questions are discussed and debated in modern times. Is 'teaching' a profession? Are university faculty members professionals? S. Sethy attempts to answer these questions by adopting qualitative methodology that subsumes descriptive, evaluative, and interpretative approaches. While answering these questions, it discusses significance and usefulness of academic ethics in the university set up. It examines role of academic ethics to offer quality education to students. Further more, it highlights university faculty members' roles and responsibilities toward students, colleagues, institution authorities, research works, and society at large. Teaching in university settings is regarded as a profession, and 
university faculty members are regarded as professionals provided they perform their duties conforming to the teacher's code of ethics $[13,14]$.

Dr. Larry Hinman, Professor of Philosophy and Director of the Values Institute at the University of San Diego, explains that ethics in a secular context have to do with what people have in common in terms of humanity. "The questions we're facing now are not how can we live well within our group, but how can our group live well with other groups in the world", Hinman says. "We need to spend a lot of time listening to what other people say about their values, rather than just making assumptions. The more we're able to see the common ground, the better our chance will be of building a strong society and a strong world" [15].

Ethics across the curriculum should begin in primary school. The Philosophy for Children movement recognizes the importance of teaching philosophy in primary school. The movement introduces dedicated philosophy courses into the primary curriculum and restricts them to explorations of logic and epistemology. Ethics is embedded in the curriculum as the foundation for communities of learning based on mutual respect. Because of the fear of parental objections, dedicated ethics courses are reserved for advanced secondary school students.

Ethics in primary schools should start with the very questions that students themselves bring to their courses. Addressing these questions will show students that their education is saturated in values. Students ask themselves, why must we take this course? Why does it have this content? Why are we using these methods? What are the alternatives? Most importantly, which of our problems does this course propose to solve? Why these problems rather than others? Why these solutions? Why not others? Further questions will help students make informed decisions about their preparation for secondary and post-secondary education. What is the relevance of this course to my graduation from primary and high school? How is what I am learning in this course relevant to my life in wider society? And the ultimate question in this time of existential crisis that Greta Thunberg has limned: what is the relevance of this course to the future of life on earth? Why should I spend my time in school when that schooling is an integral aspect of the mass extinction of life? [16].

The ethical teacher, Campbell argues, is first and foremost an ethical person, someone in whom such central moral virtues as fairness, respect, trustworthiness, honesty, and kindness have become settled dispositions which reveal themselves in the teacher's every interaction with students and constitute the very manner in which he or she teaches. Her discussion of the teacher as a moral person is, in effect, a vivid illustration of Dewey's point in How We Think that "everything the teacher does, as well as the manner in which he does it, incites the child to respond in some way or other, and tends to set the child's attitude in some way or other".

The general virtues of everyday life often transfer to the teaching context instinctively and spontaneously, of course, but often too such transfer will require professional knowledge combined with teaching experience. It will also be vital for the teacher to have a conscious grasp of relevant principles as well as an awareness of the tensions and complexities inherent in their application to particular contexts. Campbell shows how the ability to articulate and justify one's ethical principles can lead to a level of moral awareness concerning ethical complexities that might otherwise remain concealed. There are no guarantees or shortcuts here. The ongoing refinement of one's ethical insight must be a part of lifelong learning if ethical knowledge is to be attained, and this book will be a very useful resource for teachers to draw on.

One major strength is the continual reference to concrete cases and situations from classrooms. With reference to the teacher as moral educator, for example, Campbell illustrates the ethical minefields embedded in certain approaches adopted by teachers who aim to promote the acquisition of moral virtues in their students. Unexpectedly, their intentions are confounded by certain implications of their pedagogical strategies and well-meaning solutions. Bringing a problem to a talking circle, for example, has a positive effect on the students who caused the problem, but the student who was affected finds the public discussion to be humiliating. The ethical teacher needs a finely-honed sense of judgment to assess the ramifications of proposed actions, and needs to steer a careful path between such extremes as being coldly impersonal and inappropriately frank with respect to one's personal life. These general truths take on a richer and more meaningful quality when seen in the light of well-chosen examples [17].

\section{Conclusions}

The paper deals with contemporary issues of professional ethics of teachers. In this competitive world of globalization we are witnessing diverse changes in our educational system. Since change is inevitable the aims and objectives of education are changing according to the need, interests and requirements of the learn- 
ers, society and nation as a whole. The concept of teacher and teaching is also changing day by day. A teacher in this contemporary era has many duties and responsibilities. Apart from having good academic and professional qualifications, they should also possess the knowledge of professional ethics. Professional ethics is a guide, which facilitates the teacher to provide quality education and inculcate good values among the learners. The professional ethics will ensure that the teachers understand that they have a major role in bringing desirable changes in the behavior of the students. It also helps the teachers to understand their profession as a teacher. Their role is not just to become supreme authority for their students and colleagues, but that they have a wide and meaningful role to play. Teacher having the sense of professional ethics will treat the learners with love, care, affection and commitment. In addition to that, they would always ensure to make specific contribution from their angle. Therefore, this paper specially highlights the significance of professional ethics in teachers.

\title{
References
}

1 Maxwell, B. \& Schwimmer, M. (2016). Professional ethics education for future teachers: A narrative review of the scholarly writings. Journal of Moral Education, 45, 3, 354-371. DOI: 10.1080/03057240.2016.1204271

2 Campbell, E. (2000). Professional Ethics in Teaching: Towards the development of a code of practice. Cambridge Journal of Education, 30, 2, 203-221. DOI:10.1080/03057640050075198

3 Schwimmer, M., \& Maxwell, B.(2017). Codes of ethics and teachers' professional autonomy. Ethics and Education, 12(2), 141-152. DOI: 10.1080/17449642.2017.1287495

4 O’Neill, J. \& Bourke, R. (2010). Educating teachers about a code of ethical conduct.Ethics and Education, 5, 2, 159-172. DOI: $10.1080 / 17449642.2010 .516633$

5 Colnerud, G. (2006). Teacher ethics as a research problem: syntheses achieved and new issues. Teachers and Teaching, 12, 3, 365-385. DOI: 10.1080/13450600500467704

6 Aurin, K. \& Maurer, M. (1993). Forms and Dimensions of Teachers' Professional Ethics case studies in secondary schools. Journal of Moral Education, 22 (3), 277-296. DOI: 10.1080/0305724930220307

7 Nancy, K. Freeman (2000). Professional Ethics: A Cornerstone of Teachers' Preservice Curriculum. Action in Teacher Education, 22 (3), 12-18. DOI: 10.1080/01626620.2000.10463015

8 Belinova, N.V., Bicheva I.B., Kolesova O.V., Khanova T.G., \& Khizhnaya A.V. (2017). Features of professional ethics formation of the future. Espacios, Vol. 38, No. 25, 9.

9 Gluchmanova, M. (2015). The Importance of Ethics in the Teaching Profession. Procedia - Social and Behavioral Sciences, 176, 20, 509-513. Retrieved from https://doi.org/10.1016/j.sbspro.2015.01.504

10 Ewing, N.J. (2001). Teacher Education: Ethics, Power, and Privilege. Teacher Education and Special Education The Journal of the Teacher Education Division of the Council for Exceptional Children, 24, 1, 13-24. Retrieved from https://doi.org/10.1177/088840640102400104

11 Soltis, J.F. (1986). Teaching professional ethics.Journal of Teacher Education, 37, 3, 2-4. Retrieved from https://doi.org/10.1177/002248718603700301

12 Sethy, S.S. (2018). Academic Ethics: Teaching Profession and Teacher Professionalism in Higher Education Settings. Journal of Academic Ethics, 16, 4,287-299. DOI: 10.1007/s10805-018-9313-6

13 Sutton, M. (2005). The Globalization of Multicultural Education. Indiana Journal of Global Legal Studies, 12, 1, 97-108. Retrieved fromhttps://www.jstor.org/stable/10.2979/gls.2005.12.issue-1

14 Sherpa, K. (2018). Importance of professional ethics for teachers. International Education and Research Journal, 4(3), 16-18.

15 Haynes, F. (2002).The ethical school: consequences, consistency and caring. Routledge. [Google Scholar].

16 Verharen,Ch.C. (2020). The future of ethics and education: philosophy in a time of existential crises. Ethics and Education, 15, 3, 371-389. DOI: https://doi.org/10.1080/17449642.2020.1774718

17 Hare, W.(2006). The Ethical Teacher. Paideusis, Vol. 15, No 1,103-106 DOI: https://doi.org/10.7202/1072698ar

\section{Н.А. Бисембаева, С.А. Нургалиева, П.З. Ишанов \\ Ғылыми мәселе ретіндегі кәсіби этика: ғылыми дереккөздерге сипаттамалы шолу}

\begin{abstract}
Авторлар қазіргі заманның өмірлік маңызды мәселесі - педагогтардың кәсіби этикасын зерттейді. Осы мәселенің өзектілігін ескере отырып, мақала авторлары болашақ мұғалімдердің кәсіби этикасын оқыту бойынша алыс және жақын шетел авторларының ғылыми дереккөздеріне баяндау шолуына арналған зерттеуде, осы проблемалық саласындағы негізгі аспектілер бойынша көзқарастарды жинақтады. Зерттелінетін сұрақтар аспектісінде педагогикалық тәжірибелер зерттеуінде жүйелендіру және жалпылау әдістері қолданылды, осылайша авторлар алыс және жақын шетел авторларының ғылыми көзқарастарының бақылау жүйелері мен эксперименттік фактілерін келтіруге тырысқан.
\end{abstract}


Студент-түлектермен жүргізілген сұхбат нәтижелері бойынша, көпшілік респонденттер жоғары оқу орнын тамамдауда кәсіби этика саласында білімдері мен іскерліктері бойынша төмен көрсеткіштер көрсеткені байқалды, бұл болашақ кәсіби қызметтеріне жағымсыз әсер ететін болады. Зерттеу нәтижелері студенттердің - болашақ педагогтардың кәсіби этикалық қалыптастыру мәселесі бойынша ғылыми білімдерді кеңейтуге және үздіксіз кәсіби білім беру теориясы мен әдістемесі байыта отырып, тұлғаның кәсіби адамгершілік даму концепциясын және кәсіби этиканың негізгі тұжырымдамаларын толықтыруға мүмкіндік береді.

Кілт сөздер: этика, жоғары мектеп, кәсіби этика, қалыптастыру, сұхбат, бақылау, педагогикалық тәжірибе, теория және әдістеме.

\title{
Н.А. Бисембаева, С.А. Нургалиева,П.З. Ишанов \\ Профессиональная этика как научная проблема: описательный обзор научных источников
}

\begin{abstract}
Авторами исследована жизненно важная проблема современности - профессиональная этика педагогов. Учитывая актуальность данной проблемы, авторы настоящей статьи инициировали исследование, посвященное повествовательному обзору научных источников зарубежных авторов дальнего и ближнего зарубежья по обучению профессиональной этике будущих учителей, синтезируя точки зрения по ключевым аспектам данного проблемного поля. Исследование проведено методом систематизации и обобщения педагогического опыта в аспекте изучаемого вопроса, тем самым авторы предприняли попытку приведения в систему наблюдений и экспериментальных фактов научных взглядов авторов дальнего и ближнего зарубежья. По результатам интервью со студентами-выпускниками было выявлено, что у большинства респондентов к завершению вуза наблюдаются низкие показатели по знаниям и умениям в области профессиональной этики, что, в свою очередь, отрицательно скажется в их будущей профессиональной деятельности. Результаты исследования позволили расширить научные знания по проблеме формирования профессиональной этики у студентов - будущих педагогов и дополнить основные положения профессиональной этики и концепций нравственнопрофессионального развития личности, обогащая теорию и методику непрерывного профессионального образования.
\end{abstract}

Ключевые слова: этика, высшая школа, профессиональная этика, формирование, интервью, наблюдения, педагогический опыт, теория и методика. 